\title{
Evaluation of the Impact of Usability in Arabic University Websites: Comparison between Saudi Arabia and the UK
}

\author{
Mohamed Benaida, Abdallah Namoun, Ahmad Taleb \\ Faculty of Computer and Information Systems \\ Islamic University of Madinah, Saudi Arabia
}

\begin{abstract}
Today usability is a crucial factor that can affect any website. The purpose of this study is to explore major usability defects within Saudi university websites in comparison to British university websites from a Saudi student perspective. In addition, students are expected to achieve their goal when surfing a Saudi Arabian university website comfortably and efficiently without any complication. This study uses two methods to evaluate and measure usability problems; user testing and thinking aloud. Both methods are very useful and effective for collecting data from participants. Based on the ranking of the universities, 60 students were split evenly into three groups; each group was asked to evaluate a different pair of university websites from different ranking levels, one from the UK and the other from KSA. The evaluation performed by each group was gathered using the SUS (System Usability Scaling) questionnaire to find flaws within the usability of the website. During the experiment, the participants' opinions were collected using the thinking aloud method. The findings of this research showed that all Saudi universities in all tiers had significant problems within the usability of their websites. The most frequent problems found were, inconsistency, integration, confidence and satisfaction. Other less frequent problems that were found during this study were design concepts, easy use of websites and comfort of students. Saudi universities can learn from the differences in the quality between both sides to upgrade and redesign their website to achieve user satisfaction, therefore increasing the confidence of the users.
\end{abstract}

Keywords-Usability; usability evaluation; factor analysis; student satisfaction

\section{INTRODUCTION}

Students around the world today are more involved in using the internet than ever before. Nowadays, the internet has become the main core of education and the most significant characteristic that can influence the level of knowledge of any educational sector [37]. In the last two decades usability has become a crucial factor that has affected the quality and satisfaction of the users of websites [21], [23], [43]. Web design, information and system quality are variables that can deeply affect the success of usability within a website from the users' perspective [1], [34], [35], [45]. This study has allowed us to enhance the gratification of usability of educational websites in Saudi Arabia.

The contribution of this study can be summarised in several points; firstly, the lack of studies in the field of Arabic usability within educational websites is due to studies being in the initial stages, therefore this study has come to fill this gap. Besides that the comparison conducted in this study between developed and developing countries provide a clear picture about the level of educational websites in Saudi Arabia and also discover the main barriers that can influence the satisfaction of the users of Arab educational websites. Finally, this study suggests adequate solutions that are revealed by the end users which make this study more reliable.

The layout of this study is as follows: an introduction to the study was given in Section I. Deep literature review is conducted in Section II to explore previous education websites usability. The process of data collection was highlighted and a constructive method was applied in Section III. Results are presented in Section IV, evaluated in Section V and a conclusion is formed in Section VI. The final two sections are "Limitations of Study" and "Future Recommendations".

\section{LITERATURE REVIEW}

Usability has different definitions based on the field of study. The standard definition of usability according to the international standard organisation [5] is "effectiveness, efficiency and satisfaction with which a specified set of users can achieve, in a specified set of tasks in a particular environment". The author in [10] divides usability into five main factors:

- Learnability: the users should find the system easy to use and complete their task quickly

- Efficiency: the number of tasks that the user can successfully accomplish by using the system

- Memorability: the user can easily remember the system

- Errors: the user can easily recover from a system error

- Satisfaction: the user should feel pleasant when using the system.

A few studies have analysed Arabic educational usability websites. The consistency in Saudi Arabian multilingual websites was examined, one website (King Faisal University) was tested as a case study, several problems were identified, and solutions have been suggested [29]. Other studies focus on the level of usability in Jordanian university websites, the main problems faced on Jordanian websites were related to most areas in usability, such as the design of websites [19], 
[20]. Moreover, some studies [18] found that the participants failed to complete any tasks on the websites examined due to the 26 usability problems discovered which is appalling. In this study, the author explores usability problems in the Arab North African educational websites, the satisfaction of Arabic users is still so far. The websites failed to satisfy all usability variables including slow loading speed and high number of HTML objects [24]. In addition, the level of usability in a non-Arabic country was investigated [3], [40] in Turkish universities, the users found the university websites easy to use and that the websites proved to be a very useful source of information regarding the university. Arabic universities suffer from poor usability, effectiveness and learnability which are all very important to provide a smooth and spontaneous experience of these e-learning webpages [25].

Technology and computing plays a major role on the learning of students, especially in universities. Factors like presentation, collaboration and creativity are heavily influenced by technology and usability in most universities, but the use of technology should be made a mandatory part of other teaching and learning processes as well [26]. The way the users perceive websites in general and e-commerce websites in particular, are greatly affected by usability and the culture they belong to. The impact of usability on e-learning systems was analysed by [30] in which they studied a specific e-learning system and with the help of various parameters (for example participation of students in forums, blogs and messaging systems), they evaluated the performance of the system and how it impacts the students. The usability of their selected system was measured using various tests like Technology Acceptance Model and they included students from different universities. They concluded that forums had more impact on the learning of students. Recent studies regarding educational websites concentrate on the localisation and globalisation of multilingual websites, [22] suggests that these websites must be designed in a way that satisfies all users at a local as well as international level. In order to achieve a good level of usability, the website designers and developers should follow design standards and guidelines [30].

The importance of perception of usability and how it can play a role towards the initial impression of a website belonging to a university or a program is emphasised by [44], the role of first impressions of websites on the users was a major factor. Another factor that affects the perception of usability is website architecture which is very crucial for user satisfaction [32], [4]. The designers should try to build a relationship between the students and the university with the help of dialogical exchanges.

Various factors could lead to satisfaction and dissatisfaction pertaining to a particular website; perceived ease of use, perceived usefulness and perceived enjoyment. The users of the Internet are maturing so as their expectations, therefore the service providers should change their approach of designing and functionality [49]. In addition, user expectations change over time due to the rapid growth in technology, this requires the websites to renew their design in order to achieve user satisfaction. The impact of usability guidelines on the aesthetic assessment of e-commerce related websites and the perceptions of e-retailers is examined [48]; white space, background color, thumbnail image location and size are the four design factors that can change the whole perception of the user. In [50], the author examines the design issues that a multilingual user will have to experience for the user interfaces. A lot of applications are now available in multiple languages. The results show that the English version of the website is much better in terms of usability therefore, the translated versions need improvement.

\section{RESEARCH METHODOLGY}

\section{A. University Choices}

Six universities were chosen in total, three from the UK; Oxford University (Fig. 2), University of Kent (Fig. 4) and Sheffield Hallam University (Fig. 6) and three from Saudi Arabia; King Abdulaziz University (Fig. 1), Islamic University of Madinah (Fig. 3) and the Arab Open University (Fig. 5).

The reason why UK universities were chosen to make a comparison with Saudi universities is that many UK universities are on top of the world universities rankings table.

The UK university websites are designed in English which is understandable for the Saudi students because the official language of studies in Saudi Arabia is the English language.

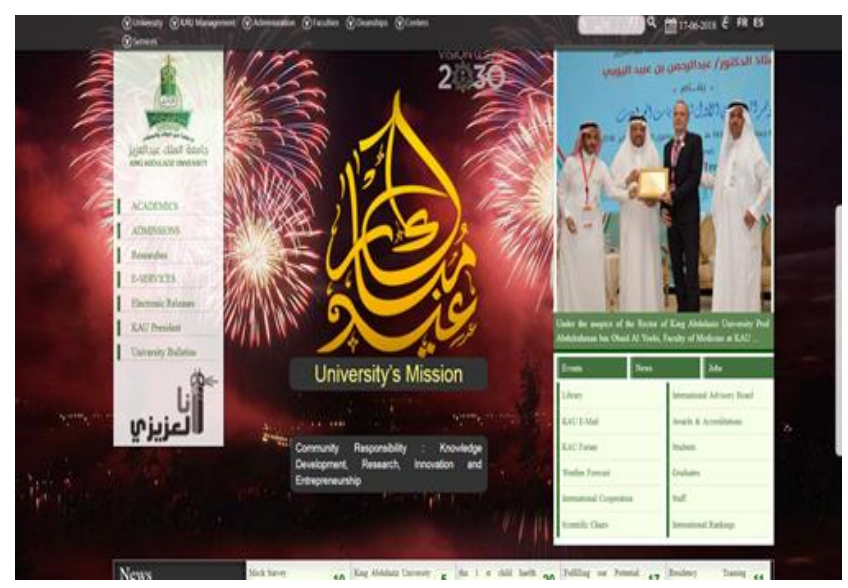

Fig. 1. King Abdulaziz University Home Page.

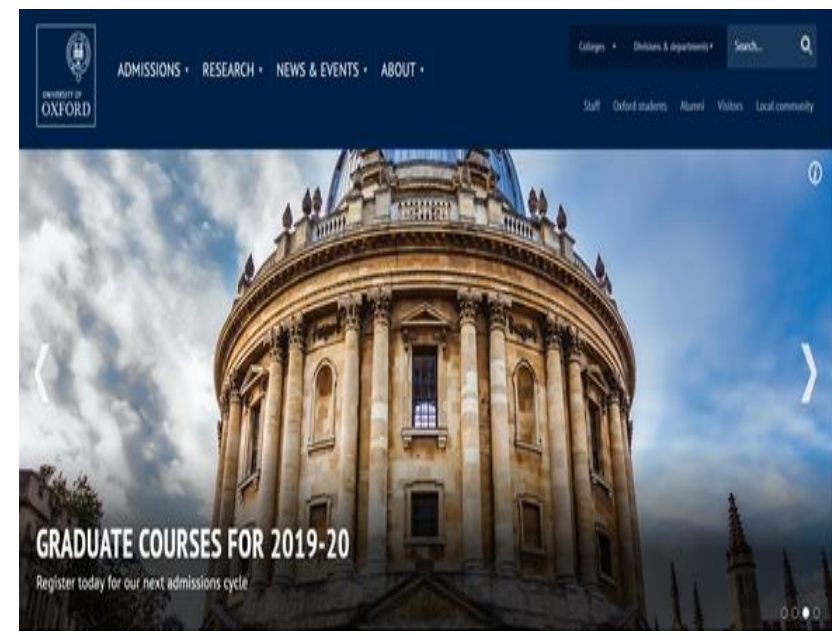

Fig. 2. Oxford University Home Page. 
There are many features offered by the university websites, like information related to the courses (description of the course, entry requirement) and services that can help students to get involved with the university (download documents, payment methods, assignment submission, online registration).

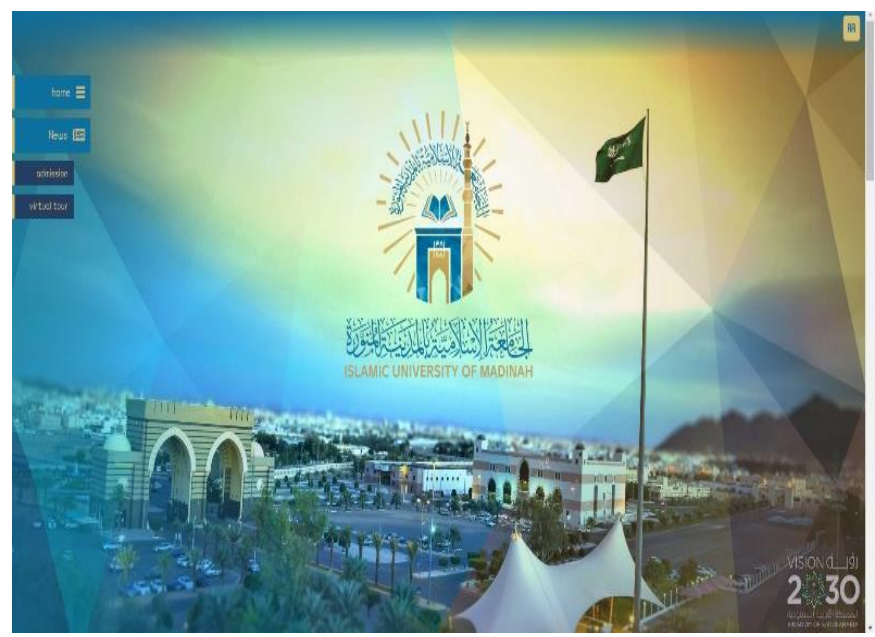

Fig. 3. Islamic University of Madinah Home Page.

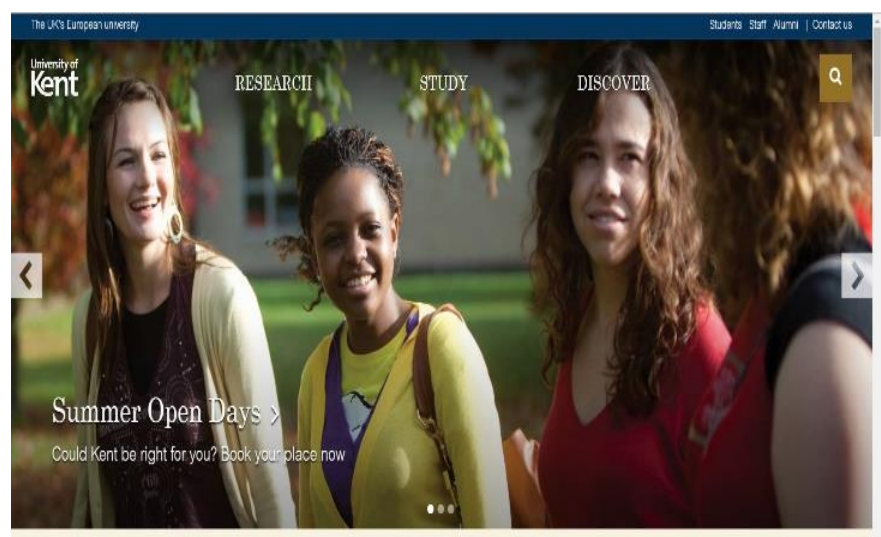

A PLACE TO INSPIRE/ AN APPROACH TO CHALLLENGE

Fig. 4. University of Kent Home Page.

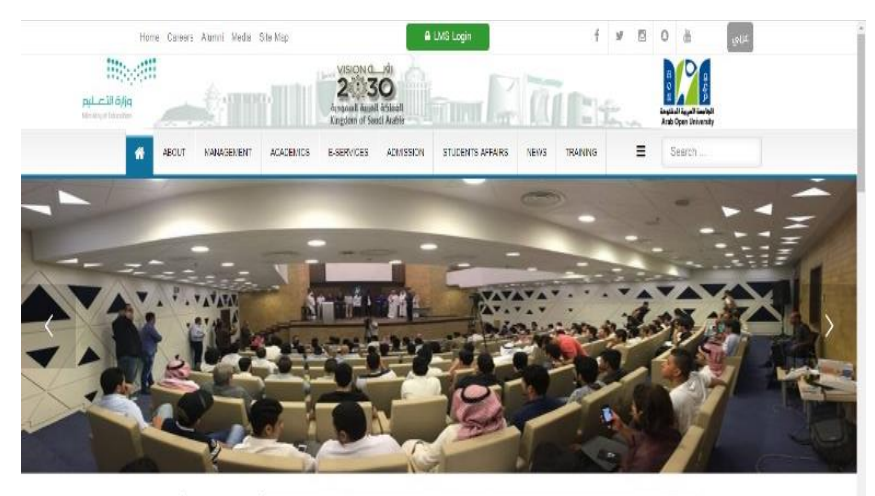

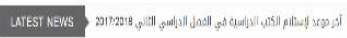

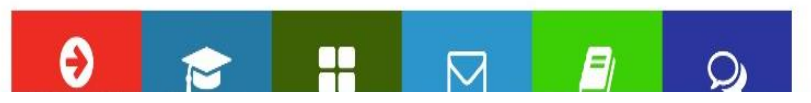

Fig. 5. Arab Open University Home Page.

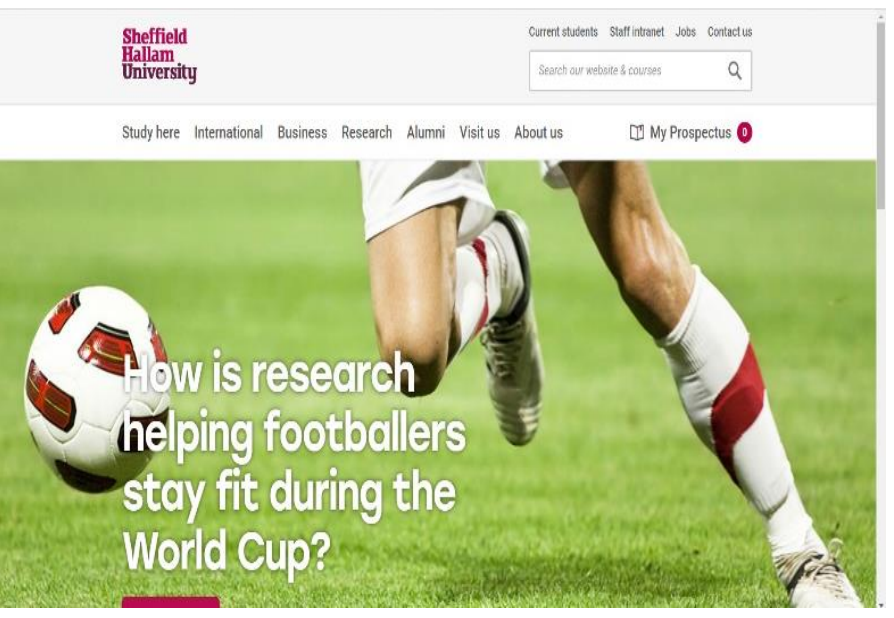

Fig. 6. Sheffield Hallam University Home Page.

For this study, six university websites split evenly between the United Kingdom and Saudi Arabia were selected in accordance to their rankings (Table I). For the first pair of universities which this study will compare, Oxford University and King Abdulaziz University were chosen. According to the Times Higher Education World University Rankings, Oxford University is ranked first nationally, similarly, King Abdulaziz University is ranked second nationally. On an international level, King Abdulaziz University is ranked 201-250, while Oxford University is ranked first internationally. The total number of students in King Abdulaziz is more than the total number of students in Oxford University (31554 and 20409 respectively). However, the percentage of international students in Oxford university is higher than the percentage of that in King Abdulaziz University, where Oxford University's percentage of international students is $38 \%$, whereas, the Saudi Arabian university has a total of $21 \%$ of international students enrolled.

The second pair of universities that were compared are mid-tier universities, therefore the University of Kent and the Islamic University of Madinah were chosen. However, when collecting statistics on the Islamic University of Madinah, there was no data found on the Times Higher Education World University Rankings website, therefore we had to resort to Webometrics. According to this website, the Saudi Arabian university is ranked $21^{\text {st }}$ nationally, while, Kent University attained a rank of 39 nationally. However, the British university is ranked 301-350 internationally, on the other hand, the Islamic University of Madinah is ranked 5119 internationally. There is a clear and drastic difference between the two universities on an international level even though the Islamic University of Madinah is ranked higher nationally. The total number of students in both universities is similar, as the University of Kent has 164949 students, while the Saudi Arabian university has a total of 20000 students. The Islamic University of Madinah has a very high percentage of international students compared to the University Kent (85\% and $31 \%$ respectively).

Finally, two universities from the lower tier of the rankings were compared, Sheffield Hallam University and the Arab Open University were selected. As seen previously with the 
Islamic University of Madinah, there was no data on the Times Higher Education World University Rankings website for the Arab Open University, therefore we referred to Webometrics. Once again, on a national level, the Saudi Arabian university is ranked higher than the British university. The Arab Open University is ranked $54^{\text {th }}$ nationally and Sheffield Hallam University achieved a rank of 90. Correspondingly, the British university is ranked higher than the Saudi Arabian university internationally. Sheffield Hallam University has been awarded a rank of 801-1000, on the other hand the Arab Open University was 14453 on the international ranking tables on Webometrics. The total number of students as mentioned on the Arab Open University website is 15396. Unlike the previous two pairs of universities compared, where the total number of students was always higher in the Saudi Arabian university, Sheffield Hallam University has more students than the Arab Open University since the British university has 24627 students, of which $14 \%$ are international students.

TABLE I. UNIVERSITIES WEB RANKING AND NUMBER OF STUDENTS

\begin{tabular}{|l|l|l|l|l|}
\hline University & $\begin{array}{l}\text { National } \\
\text { Ranking }\end{array}$ & $\begin{array}{l}\text { International } \\
\text { Ranking }\end{array}$ & $\begin{array}{l}\text { Number } \\
\text { of } \\
\text { Students }\end{array}$ & $\begin{array}{l}\text { Percentage of } \\
\text { International } \\
\text { Students }\end{array}$ \\
\hline $\begin{array}{l}\text { Oxford } \\
\text { University }\end{array}$ & 1 & 1 & 20409 & 38 \\
\hline $\begin{array}{l}\text { King } \\
\text { Abdulaziz } \\
\text { University }\end{array}$ & 2 & $201-250$ & 31554 & 21 \\
\hline $\begin{array}{l}\text { University } \\
\text { of Kent }\end{array}$ & 39 & $301-350$ & 16949 & 31 \\
\hline $\begin{array}{l}\text { Islamic } \\
\text { University } \\
\text { of Madinah }\end{array}$ & 21 & 5119 & 20000 & 85 \\
\hline $\begin{array}{l}\text { Sheffield } \\
\text { Hallam } \\
\text { University }\end{array}$ & 90 & $801-1000$ & 24627 & 14 \\
\hline $\begin{array}{l}\text { Arab Open } \\
\text { University }\end{array}$ & 59 & 14453 & 15396 & $\mathrm{n} / \mathrm{a}$ \\
\hline
\end{tabular}

\section{B. Participants}

All 60 students who were selected to participate in this study are Saudi male university students aged between 19-25 years, most of them are undergraduate students $(85 \%)$ and the rest are postgraduate level (15\%). To avoid any bias each twenty students evaluated and compared between two websites, one from each country (UK and KSA), each participant spent around twenty minutes to take a tour inside the website.

\section{Evaluation Methods}

To explore and evaluate usability problems, two methods are used, experiment, user testing [47], [2] and thinking aloud [31]:

1) Thinking aloud method: Thinking aloud usability testing method is one of the most effective evaluation methods and most widely used method in usability testing [10], [32] This method supports the user to think aloud and share their thoughts and emotions while carrying out tasks whilst the user is being observed. One of the benefits of this method is that it allows the researcher to comprehend and understand why the user undertakes a specific decision. [27], [28]. Thinking aloud method offers comprehensive details of the information seeking process [42].

2) Experiment (user testing) method: User testing is one of the most widely used methods to evaluate website design and to examine the level of usability [47]. Since user testing is the most efficient evaluation method, it is the main method in usability testing [10].

\section{Data Collection Process}

During the experiment, the participants spoke aloud and then the researcher recorded what was verbalised and took notes during the experiment. Besides that, the participants answered the SUS questionnaire [17] after they spent twenty minutes exploring the website to familiarise with it. Sixty Saudi students compared six websites, one from the UK and the other from KSA, the students were divided into 3 groups each group having 20 students, where they examined and evaluated two websites.

Overall sixty student responses were collected for the comparison between the websites. The SUS questionnaire was selected because it is more accurate, reliable and valid, based on many previous studies [6], [12]-[16], [41].

Moreover, it is the most appropriate method that can be used to compare between different websites (coefficient alpha of .91) [41]. The advantage of SUS is that it can be summarised as being a short list of questions and free to use [39]. The SUS questionnaire contains ten questions, after the participant is familiar with the website (spends twenty minutes before answering certain questions) they are asked to read each question carefully and fill the questionnaire by using the scale (five-point Likert-type scale) from " 1 " which is strongly disagree to " 5 " which is strongly agree.

\section{RESULTS}

Two powerful methods are used to collect data in this experiment, user testing method and thinking aloud method. The following Tables II, III and IV show the results collected from the students in Saudi Arabian universities.

Table II shows the comparison of usability between Oxford University and King Abdulaziz University. We started our data collection by interviewing 60 students to identify usability flaws in university websites. The students were divided into three groups each group contained 20 students 
where they explored usability problems after comparing two websites by completing SUS questionnaire.

The results for King Abdulaziz University website were more varied in comparison to Oxford university website throughout the questionnaire. The results show that $100 \%$ of students strongly agreed/agreed that they will continue using Oxford University website frequently as the average score was 4.9, while only $15 \%$ agreed to use King Abdulaziz University website frequently with a low score of 2.8 .

This partially leads on to the next question where $100 \%$ disagreed that the University website was unnecessarily complex with an average score of 1.15, there is a clear correlation between the first two questions, it is expected that if a website is unnecessarily complex, it will disengage the audience and discourage them from revisiting the website, hence the almost perfect correlation between the first two questions in the questionnaire which is why the Saudi University was given a considerably high score of 3.25. In fact, questions two to nine all dictate the results shown in question one. Oxford University achieved a score of 4.75 since most interviewees believed the website was easy to use, whereas King Abdulaziz University scored 3.8 which is respectable. This has a direct link to the next question in the questionnaire, if the students found the website easy to use they would not need the help of an assistant to use the website, therefore Oxford University scored a very low and good score of 1.2 and the Saudi website also scored a good score of 1.55 which is in association to the scores given in the second question.

The fifth question talked about how well the functions were integrated within the website in which Oxford University was given an average score of 4.55 , however King Abdulaziz University had a very low score of 2.75. The students believed that there was too much inconsistency in the Saudi website therefore it achieved a score of 3.8, whereas the Oxford University was deemed to be quite consistent as a result attaining a score of 2. Question seven has a direct link to question three, if the user found the website easy to use then they would believe that others would also find it easy to use and vice versa. For Oxford University the scores for question 3 and 7 were almost similar (4.75 and 4.8 respectively), King Abdulaziz University scores were also very similar as it achieved a score of 3.2 (3.3 in question 3), this proves the clear and distinct correlation.

Question eight discusses how cumbersome the website was to use, Oxford University was given an average score of 1.1 which is perfect and the Saudi website had a score of 1.7. Most students felt very confident using the Oxford University website (score of 4.3) and the number of students who did not feel confident using King Abdulaziz website had a score of 2.85. The final question involves how quickly the user got accustomed to the website, when using the Saudi website, most students got accustomed to the website quickly and this gave King Abdulaziz University a score of 2.4 on this question, the Oxford University website was easier hence they achieved a better score of 1.35 .

The average overall SUS Score indicates how successful a website is (in this case the two university websites chosen) in which the Oxford University website gained an exceptional score of 91.0 (grade A+) whereas the King Abdulaziz University website gained a poor score of 55.5 which means that the Saudi university website requires intense adjustments in order to achieve a higher score.

Table III shows the comparison between the University Kent's website and the Islamic University of Madinah's website. The second set of 20 students gave their opinions on the university websites via filling out the SUS questionnaire.

The first question discusses whether or not the user would revisit the website, the University of Kent achieved an average score of 4.8 which is close to perfect, whereas the Islamic University of Madinah achieved an average score of 3.3 which on the other hand is respectable. Question two talks about the simplicity of the website where 1 on the scale means perfection since the questions states "I found this website to be unnecessarily complex", therefore 5 on the scale would be the worst score that can be given; the University of Kent scored 1.9 and the Islamic University of Madinah scored 2.5 which is quite close to the score awarded to the University of Kent, this data is normally distributed as most of the student answers were spread out from 1-2 and 4-5, but compact in the middle as half of the students awarded the University of Kent a score of 3 .

Question three questions how easy it was for the user to navigate through the website, the Saudi university website had been awarded a score of 3.1 whereas on the other hand the British university was given a score of 4.35 as most students believed that it was easy to use the website. Question four relates somewhat to the previous question, if the website was easy to use there would be no need for an assistant which is exactly what this question is asking ("I will need the help of a support person"), hence we would expect the results to be almost simultaneous; since Kent university was given a high score in question three it is expected to have a low score on question four, this university achieved a score of 1.1 where only $10 \%$ of the students gave it a score of 2, unlike the Islamic University of Madinah where the results were more spread out and the average score was 3 .

For question five, the students gave the Saudi Arabian website a score of 2.2 however they awarded the University of Kent a score of 4.7 which is exceptional. The level of consistency is the topic of the next question, where the students provided the Islamic University of Madinah with a score of 3.7 which needs to be improved on, on the other hand the University of Kent was assigned with a score of 1.5 which is remarkable.

For the next question the students are asked if they think other people would learn to use this website very quickly which is very subjective and would be based on whether or not the students found the website easy to use themselves, therefore we would expect the results from question three and this question to be very similar. The University of Kent received a score of 4.8 (in question three 4.35) and the Islamic University of Madinah received a score of 2.9 and in question three they attained a score of 3.1. In question seven, the students were asked about how cumbersome they found the website to be, most students gave the University of Kent a 
score of 1 which gave an average score of 1.2 , however the Saudi Arabian university was awarded a score of 3.1. The level of confidence was examined in the next question, students felt much more confident using the University of Kent website than the Islamic University of Madinah (a score of 4.7 and 2.7 respectively).

For the final question, almost all students strongly disagreed with this statement with regards to the University of Kent website, thus receiving an average score of 1.25 , conversely, the Islamic University of Madinah attained a score of 3.35. These ten questions are combined and give an average overall SUS score which proves how well a website is being run. In this case the Islamic University of Madinah had an overall score of 46.4 which on the Curved Grading Scale for the SUS is in the lowest tier (Grade F), [11].

Table IV of this experiment includes Sheffield Hallam University and the Arab Open University. For the first question which states "I would like to use this website frequently", the Sheffield Hallam University achieved a score of 3.5, whereas the Arab Open University achieved a similar score of 3.1. In the second question it discussed how complex the participants found the website to be, Sheffield Hallam University received a score of 2.05 unlike the Arab Open University which achieved a less satisfying score of 2.25 (for this question the higher the mark the lower the total SUS Score).

Question three discusses the ease of use regarding the website from the student's perspective, results show that students believed that the Sheffield Hallam University website was easier to use hence a score of 4.15 was awarded; therefore the Arab Open University attained a lower score of 3.9. Question four says "I would need the help of a support person" which means that the participants struggled to use this website, Sheffield Hallam University attained a score of 1.35, while the Saudi university achieved a score 1.8 which is also respectable. Sheffield Hallam University achieved a high score of 4.1, whereas the Arab Open University achieved a poor score of 2.45 .

Question six discusses the level of consistency, where Sheffield Hallam University was thought to be more consistent than the Arab Open University achieving scores of 1.8 and 3.95 respectively (for this question the higher the mark the lower the total SUS Score). For question seven, participants were asked to comment on if they believed other people will adapt to this website very quickly or not, for the Sheffield Hallam University website most people believed that it was quite easy to understand and adapt to, hence receiving a score of 3.9, however the Arab Open University wasn't as easy to learn to use, as a result receiving a marginally lower score of 3.6.

Question eight enquires about how cumbersome the website was to use, Sheffield Hallam University achieved a score of 1.5 whereas the Arab Open University achieved a score of 2.1 (for this question the higher the mark the lower the total SUS Score) where both scores are respectable. For question nine, participants were asked to comment on how confident they were when using the website, both universities achieved the exact same score of 2.6. In the final question, students were asked to discuss if they needed to learn a lot of things before they could get going with the website; Sheffield Hallam University achieved a score of 2.2 while the Arab Open University received a score of 2.6.

These ten scores were used to calculate an overall average SUS score in which Sheffield Hallam received an overall score of 69.3, whereas the Arab Open University achieved an overall SUS score of 61.5. Table V shows universities scores based on SUS questionnaire scales and total SUS scored by each University

TABLE II. COMPARISON BETWEEN OXFORD UNIVERSITY (GREEN) AND KING ABDULAZIZ UNIVERSITY (ORANGE)

\begin{tabular}{|c|c|c|c|c|c|}
\hline & $\begin{array}{l}\text { Strongly } \\
\text { Disagree (1) }\end{array}$ & 2 & 3 & 4 & $\begin{array}{l}\text { Strongly } \\
\text { Agree (5) }\end{array}$ \\
\hline \multirow{2}{*}{$\begin{array}{l}\text { 1. I think that I } \\
\text { would like to use } \\
\text { this system } \\
\text { frequently. }\end{array}$} & & & & 10 & 90 \\
\hline & 5 & 30 & 45 & 20 & \\
\hline \multirow{2}{*}{$\begin{array}{l}\text { 2. I found the website to } \\
\text { be unnecessarily } \\
\text { complex. }\end{array}$} & 85 & 15 & & & \\
\hline & & 20 & 40 & 35 & 5 \\
\hline \multirow{2}{*}{$\begin{array}{l}\text { 3. I thought the website } \\
\text { was easy to use. }\end{array}$} & & 5 & & 10 & 85 \\
\hline & 5 & 25 & 20 & 35 & 15 \\
\hline \multirow{2}{*}{$\begin{array}{l}\text { 4. I think that I } \\
\text { would need the } \\
\text { support of a technical } \\
\text { person to be able to } \\
\text { use this system. }\end{array}$} & 80 & 20 & & & \\
\hline & 55 & 35 & 10 & & \\
\hline \multirow{2}{*}{$\begin{array}{l}\text { 5. I found the } \\
\text { various functions in } \\
\text { this website were } \\
\text { well integrated. }\end{array}$} & & 5 & 5 & 20 & 70 \\
\hline & 10 & 30 & 35 & 25 & \\
\hline \multirow{2}{*}{$\begin{array}{l}\text { 6. I thought there was } \\
\text { too much } \\
\text { inconsistency in this } \\
\text { website. }\end{array}$} & 10 & 80 & 10 & & \\
\hline & & 15 & 20 & 35 & 30 \\
\hline \multirow{2}{*}{$\begin{array}{l}\text { 7. I would imagine } \\
\text { that most people } \\
\text { would learn to use this } \\
\text { system very quickly. }\end{array}$} & & & 5 & 10 & 85 \\
\hline & 10 & 30 & 45 & 15 & \\
\hline \multirow{2}{*}{$\begin{array}{l}8 . \text { I found the system } \\
\text { very cumbersome to } \\
\text { use. }\end{array}$} & 90 & 10 & & & \\
\hline & 45 & 40 & 15 & & \\
\hline \multirow{2}{*}{$\begin{array}{l}\text { 9. I felt very confident } \\
\text { using the system. }\end{array}$} & 80 & 10 & 10 & & \\
\hline & 10 & 25 & 35 & 30 & \\
\hline \multirow{2}{*}{$\begin{array}{l}\text { 10. I needed to learn a } \\
\text { lot of things before I } \\
\text { could get going with } \\
\text { this system. }\end{array}$} & 75 & 15 & 10 & & \\
\hline & 15 & 35 & 45 & 5 & \\
\hline
\end{tabular}


TABLE III. COMPARISON BETWEEN THE UNIVERSITY OF KENT (WHITE) AND ISLAMIC UNIVERSITY OF MADINAH (BLUE)

\section{The SUS Questionnaire}

\begin{tabular}{|c|c|c|c|c|c|}
\hline & $\begin{array}{l}\text { Strongly } \\
\text { Disagree (1) }\end{array}$ & 2 & 3 & 4 & $\begin{array}{l}\text { Strongly } \\
\text { Agree (5) }\end{array}$ \\
\hline \multirow{2}{*}{$\begin{array}{l}\text { 1. I think that I would } \\
\text { like to use this system } \\
\text { frequently. }\end{array}$} & & & 5 & 10 & 85 \\
\hline & & 20 & 45 & 20 & 15 \\
\hline \multirow{2}{*}{$\begin{array}{l}\text { 2. I found the system } \\
\text { unnecessarily complex. }\end{array}$} & 35 & 40 & 25 & & \\
\hline & 10 & 35 & 50 & 5 & \\
\hline \multirow{2}{*}{$\begin{array}{l}\text { 3. I thought the system was } \\
\text { easy to use. }\end{array}$} & & & 5 & 55 & 40 \\
\hline & & 20 & 35 & 30 & 15 \\
\hline \multirow{2}{*}{$\begin{array}{l}\text { 4. I think that I would } \\
\text { need the support of a } \\
\text { technical person to be able } \\
\text { to use this system. }\end{array}$} & 90 & 10 & & & \\
\hline & & 25 & 55 & 15 & 5 \\
\hline \multirow{2}{*}{$\begin{array}{l}\text { 5. I found the various } \\
\text { functions in this system } \\
\text { were well integrated. }\end{array}$} & & & & 30 & 70 \\
\hline & 20 & 55 & 10 & 15 & \\
\hline \multirow{2}{*}{$\begin{array}{l}\text { 6. I thought there was too } \\
\text { much inconsistency in this } \\
\text { system. }\end{array}$} & 55 & 40 & 5 & & \\
\hline & & & 55 & 20 & 25 \\
\hline \multirow{2}{*}{$\begin{array}{l}\text { 7. I would imagine that } \\
\text { most people would learn to } \\
\text { use this system very } \\
\text { quickly. }\end{array}$} & & & & 20 & 80 \\
\hline & 20 & 25 & 20 & 15 & 20 \\
\hline \multirow{2}{*}{$\begin{array}{l}\text { 8. I found the system very } \\
\text { cumbersome to use. }\end{array}$} & 80 & 20 & & & \\
\hline & & 25 & 40 & 35 & \\
\hline \multirow{2}{*}{$\begin{array}{l}\text { 9. I felt very confident using } \\
\text { the system. }\end{array}$} & & & 5 & 20 & 75 \\
\hline & 25 & 25 & 30 & 15 & 10 \\
\hline \multirow{2}{*}{$\begin{array}{l}\text { 10. I needed to learn a lot } \\
\text { of things before I could get } \\
\text { going with this system. }\end{array}$} & 85 & 15 & & & \\
\hline & & 20 & 25 & 55 & \\
\hline
\end{tabular}

TABLE IV. COMPARISON BETWEEN SHEFFIELD HALLAM UNIVERSITY (GREY) AND ARAB OPEN UNIVERSITY (YELLOW)

The SUS Questionnaire

\begin{tabular}{|c|c|c|c|c|c|}
\hline & \begin{tabular}{l|} 
Strongly \\
Disagree (1)
\end{tabular} & & 3 & 4 & $\begin{array}{l}\text { Strongly } \\
\text { Agree } \\
(5)\end{array}$ \\
\hline \multirow{2}{*}{$\begin{array}{l}\text { 1. I think that I would } \\
\text { like to use this system } \\
\text { frequently. }\end{array}$} & & 10 & 40 & 40 & 10 \\
\hline & & 20 & 50 & 30 & \\
\hline \multirow{2}{*}{$\begin{array}{l}\text { 2. I found the system } \\
\text { unnecessarily complex. }\end{array}$} & 35 & 30 & 30 & 5 & \\
\hline & 20 & 35 & 45 & & \\
\hline \multirow{2}{*}{$\begin{array}{l}\text { 3. I thought the system was } \\
\text { easy to use. }\end{array}$} & & & 15 & 55 & 30 \\
\hline & & & 35 & 40 & 25 \\
\hline \multirow{2}{*}{$\begin{array}{l}\text { 4. I think that I would } \\
\text { need the support of a } \\
\text { technical person to be } \\
\text { able to use this system. }\end{array}$} & 70 & 25 & 5 & & \\
\hline & 45 & 30 & 25 & & \\
\hline \multirow{2}{*}{$\begin{array}{l}\text { 5. I found the various } \\
\text { functions in this system } \\
\text { were well integrated. }\end{array}$} & & 10 & 10 & 40 & 40 \\
\hline & 5 & 55 & 30 & 10 & \\
\hline \multirow{2}{*}{$\begin{array}{l}\text { 6. I thought there was too } \\
\text { much inconsistency in } \\
\text { this system. }\end{array}$} & 40 & 40 & 20 & & \\
\hline & & & 35 & 35 & 30 \\
\hline \multirow{2}{*}{$\begin{array}{l}\text { 7. I would imagine that } \\
\text { most people would learn } \\
\text { to use this system very } \\
\text { quickly. }\end{array}$} & & & 30 & 50 & 20 \\
\hline & & 10 & 40 & 30 & 20 \\
\hline \multirow{2}{*}{$\begin{array}{l}\text { 8. I found the system very } \\
\text { cumbersome to use. }\end{array}$} & 55 & 40 & 5 & & \\
\hline & 35 & 30 & 25 & 10 & \\
\hline \multirow{2}{*}{$\begin{array}{l}\text { 9. I felt very confident } \\
\text { using the system. }\end{array}$} & 25 & 30 & 10 & 35 & \\
\hline & 10 & 25 & 55 & 10 & \\
\hline \multirow{2}{*}{$\begin{array}{l}\text { 10. I needed to learn a lot } \\
\text { of things before I could } \\
\text { get going with this } \\
\text { system. }\end{array}$} & 20 & 40 & 40 & & \\
\hline & 10 & 30 & 50 & 10 & \\
\hline
\end{tabular}

TABLE V. UNIVERSITY SCORES BASED ON SUS QUESTIONNAIRE SCALES AND TOTAL SUS SCORE OF EACH UNIVERSITY

\begin{tabular}{|c|c|c|c|c|c|c|c|c|c|c|c|}
\hline & Q1 & Q2 & Q3 & Q4 & Q5 & Q6 & Q7 & Q8 & Q9 & Q10 & SUS Score \\
\hline Oxford University & 4.9 & 1.15 & 4.75 & 1.3 & 4.55 & 2 & 4.8 & 1.9 & 4.3 & 1.35 & 91 \\
\hline $\begin{array}{l}\text { King Abdualziz } \\
\text { University }\end{array}$ & 2.8 & 3.25 & 3.3 & 1.55 & 2.75 & 3.8 & 3.2 & 1.7 & 2.85 & 2.4 & 52.9 \\
\hline University of Kent & 4.8 & 1.9 & 4.35 & 1.1 & 4.7 & 1.5 & 4.8 & 1.2 & 4.7 & 1.25 & 90.8 \\
\hline $\begin{array}{l}\text { Islamic University } \\
\text { of Madinah }\end{array}$ & 3.3 & 2.5 & 3.1 & 3 & 2.2 & 3.7 & 2.9 & 3.1 & 2.7 & 3.35 & 46.4 \\
\hline $\begin{array}{l}\text { Sheffield Hallam } \\
\text { University }\end{array}$ & 3.5 & 2.05 & 4.15 & 1.35 & 4.1 & 1.8 & 3.9 & 1.5 & 2.6 & 2.2 & 73.4 \\
\hline $\begin{array}{l}\text { Arab Open } \\
\text { University }\end{array}$ & 3.1 & 2.25 & 3.9 & 1.8 & 2.45 & 3.95 & 3.6 & 2.1 & 2.6 & 2.6 & 57.4 \\
\hline
\end{tabular}




\section{DISCUSSION}

The following section will discuss the results found in the previous section, where Arabic university websites are going to be compared to British university websites.

Usability is an important factor to evaluate and measure different websites. Moreover, the quality of designing a website plays a major role in the usability factor [9], [34]. This study used the SUS questionnaire and thinking aloud method as the main resources to analyse the level of usability between two sites. The idea behind using SUS questionnaire is that it measures how good or bad the website is and the level of satisfaction regarding the users [13], [14]. The average score generally is 68, anything below suggests there are serious problems with the website usability. However, if it is above 68 then the satisfaction of users when discovering the website is high. [8], [38]. In order to get a grade A, a score of 80.3 or above is required which may lead to users recommending the website to others. 68 is graded as C and 51 is graded F indicating serious problems with the site, therefore an urgent review of the website must be made.

The aim of this study is to explore usability problems within Saudi university websites in comparison with the UK university websites by applying the SUS methods and 'Thinking aloud method' to measure the usability of the websites. The results of this study illustrated that students of the Saudi university faced various usability problems throughout the experiment. The most common usability problems found by students were satisfaction, integration and confidence regarding King Abdulaziz University website.

The satisfaction of students directly affects their confidence, for that reason they are not willing to use the website frequently. This consequently affected the confidence of students when using the website. Besides that, the results also showed that various functions in the King Abdulaziz University website were not integrated well. This is evident from the website where the text, icons and images are not fully integrated. Fig. 7 shows the bad integration of the website, for example when a drop icon is selected a black line appears instead of drop menu. Another example of bad integration in the website is shown in Fig. 8 where the writing clearly. The student can use the website without the need for help and this consequently affects the ease of use of the website in a positive way i.e. ease of use does not mean the usability of the website is efficient and effective [36], [46].

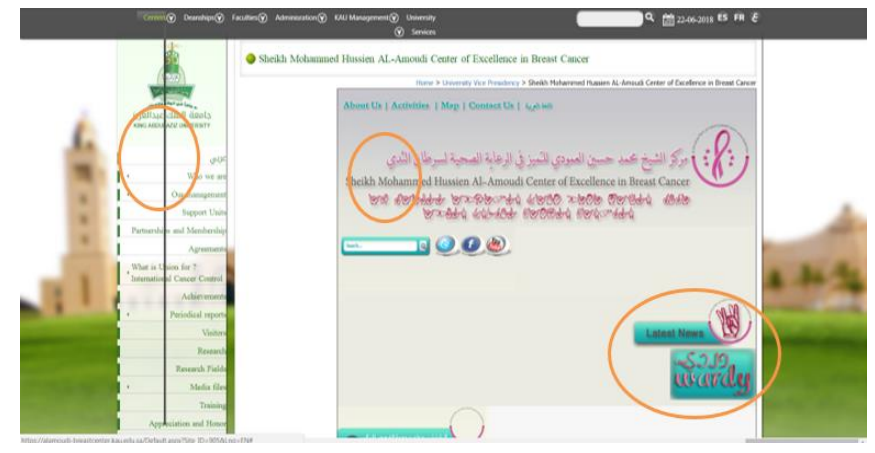

Fig. 7. Black Line Shows Poor Integration.

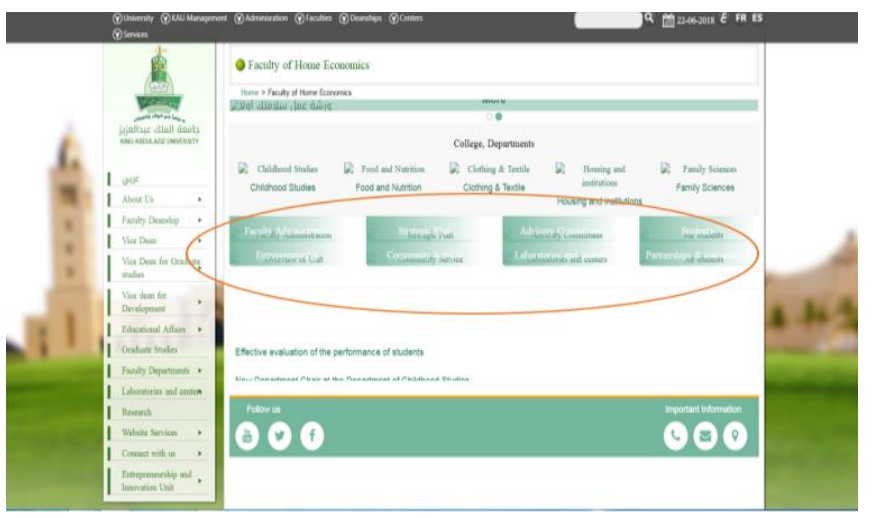

Fig. 8. Writing Overlaps.

Overall Oxford University scored 91.0 which means most students were satisfied to use the website without facing major usability problems, while the average score of King Abdulaziz University was 52.9 which is grade D which shows there are serious problems with the website. This indicates that the King Abdulaziz University website requires urgent review and may need to be redesigned to achieve user satisfaction. King Abdulaziz University can utilise the Oxford University website and use it as a base to improve its own website since it scored a very good score (91.0).

Moving on, the University of Kent had an overall score of 90.8 which is an outstanding score of A+ (the highest score that can be achieved on this grading scale) compared to that of Islamic University which scored 46.4 (grade F). This indicates that most of the students were not satisfied with the Islamic University website based on the average score, consequently meaning the website requires a major overhaul. For that reason, since the University of Kent scored very high, the Islamic University website can use that as a base when redesigning their website.

The results obtained indicates there are various usability problems within the Islamic University website. These problems were identified as integration, inconsistency of the website, learning how to use the website quickly and finally confidence when using the website. Integration and inconsistency are mutually inclusive, this is evident from the student's response. The website contained plenty of examples of how integration is poor and there is no consistency in the majority of pages of the website, as an example, when the students were asked to observe the website before filling the questionnaire they found many problems within a short time, for example when some of them wanted to search about some courses they discovered there is no search engine to help them navigate through the website (Fig. 11), secondly they could not find any information about the majority of courses in different faculties, the only information that was available is some announcements in a few faculties which are not updated. In addition, the Arabic writing was aligned from left to right, when instead it should be right to left (Fig. 10). It was also difficult to find any information when navigating within the faculty pages. The poor quality of images (Fig. 9), within the website in general and the structure of the websites was very bad based on student's response this included icons, images, text, language and font type. 


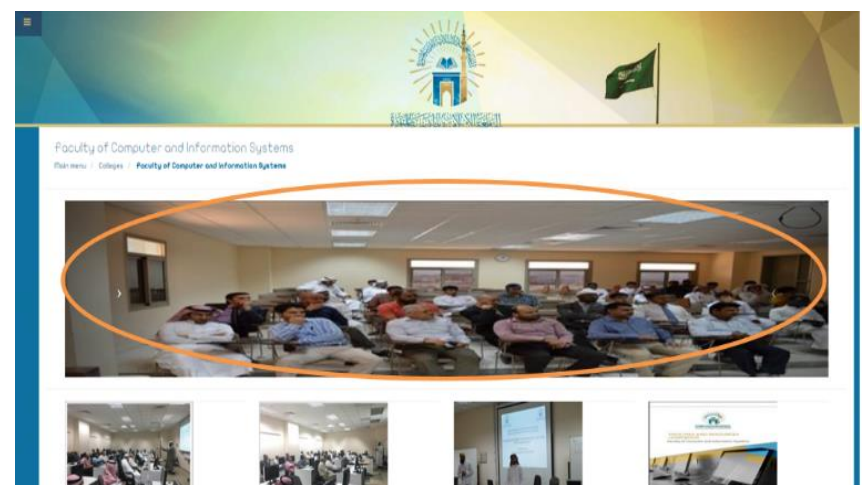

Fig. 9. Image Being Stretched, Lowering Quality.

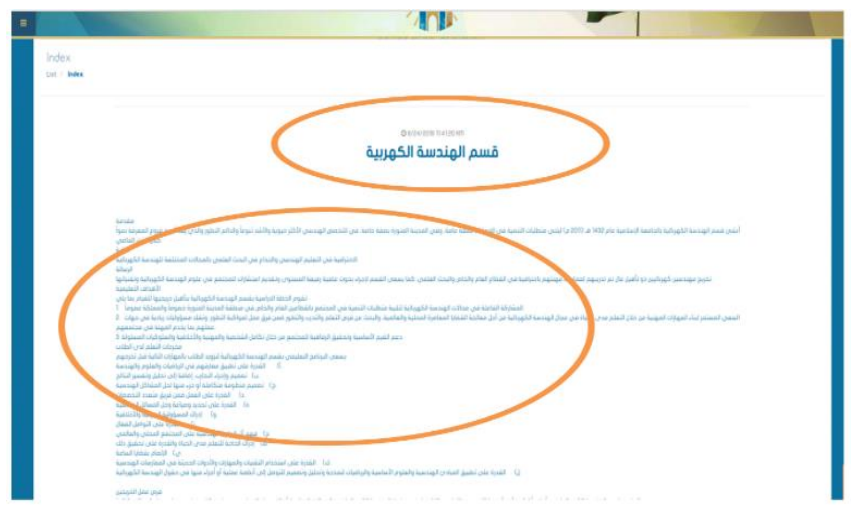

Fig. 10. Arabic Writing should be from Right to Left.

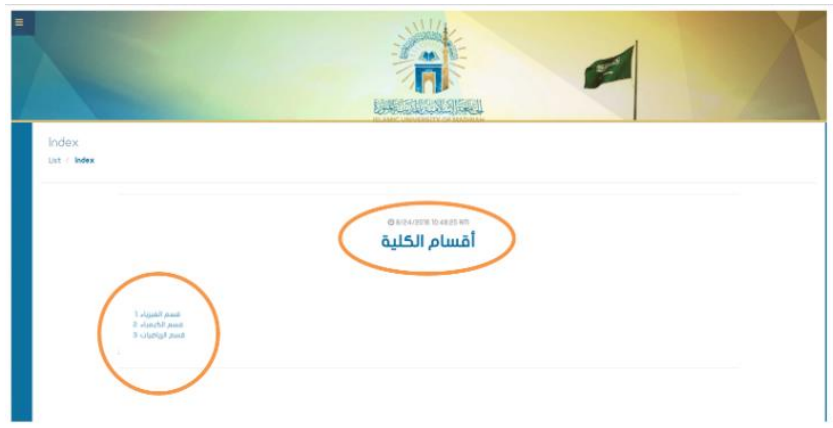

Fig. 11. English Page Shows Arabic Writing, No Search Engine.

By using the 'Thinking aloud method' students identified certain problems with the website which are shown in Fig. 12 where the page wasn't fully translated to English. Since the integration of the website was below standard, this led to certain aspects of the website design being poor. In addition to that students found that it was difficult to learn how to use the website quickly. One of the reasons which may contribute to this factor is that the English website is not fully translated from Arabic to English which may cause confusion amongst non-Arabic speakers. Another apparent problem was that after selecting an option from the menu bar at the home page there is no option available to help navigate through the website (i.e. changing from one faculty to another) as you are forced to go back to the home page and select from the menu bar again. The majority of the students did not feel comfortable using the website due to the lack of integration, inconsistency in translation and difficulty to use the website easily.

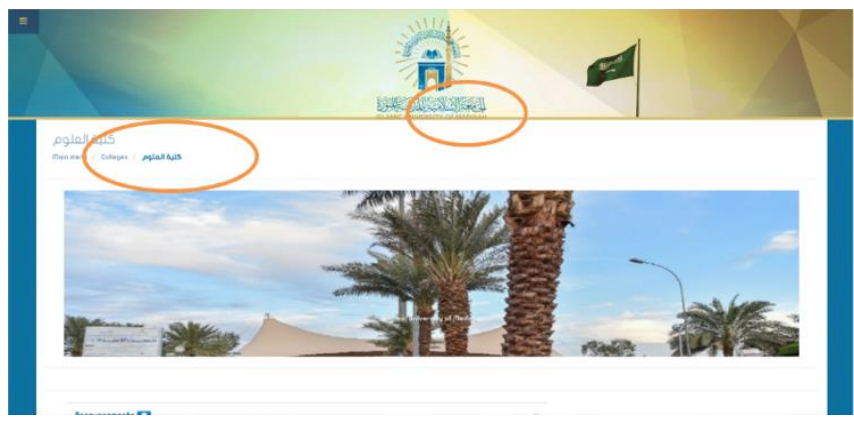

Fig. 12. Once Again Arabic Writing on English Page.

In contrast the University of Kent website gained high scores and attracted students based on various points, the main ones being very quick to learn regarding how to use the website followed by the ease of navigation, good integration of site and consistency of the website. These are the main factors that influenced the confidence and the satisfaction of Saudi Arabian students whom used the website.

The comparison between websites was chosen to evaluate the lower ranked universities in the UK as well as Saudi Arabia. Sheffield Hallam University and the Open Arab University were examined during this study. The total score for Sheffield Hallam University was 73.4 (grade B-) whilst the Arab Open University was 57.4 (grade D). Sheffield Hallam University website requires some attention to improve the usability of the website such as satisfaction of students, for example when the 'Study here' option on the navigation bar is selected various options pop up. When 'find a course' is selected, another 'find a course' will appear again (Fig. 13) which confused the students since the same terminology was used twice without them being differentiated. To solve this, it would be better if the colour of the subtitle was changed or one of the two icons was renamed.

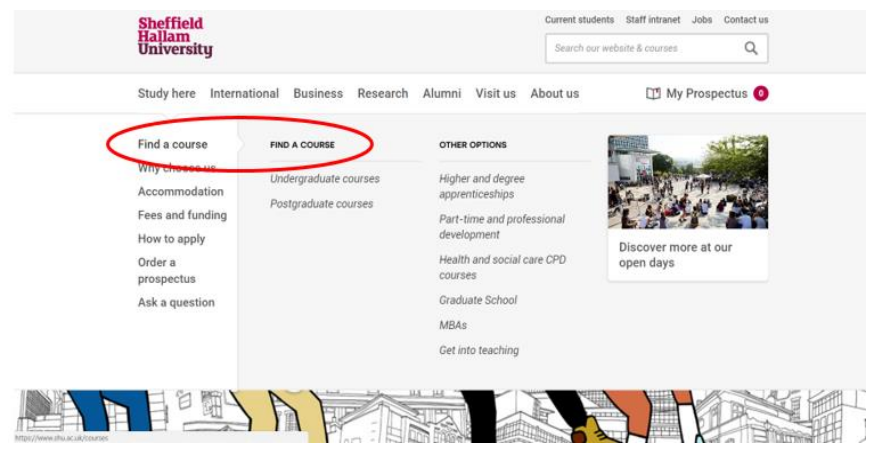

Fig. 13. 'Find A Course' Option Shown Multiple Times.

Based on the comments of the students, it was clear that their confidence had decreased. This was observed via 'Thinking aloud method'. The two main problems that were identified within the Arab Open University website included inconsistency and integration. The main function of any university website is to offer enough information with content about the types of facilities available, the type of courses available (graduate and undergraduate), fees and funding, international/national applications and student life. This is not the case for the Arab Open University as the students found that within the faculty page detailed information about each 
faculty and its departments (i.e. courses) was not available as shown in Fig. 14. This ultimately affects the inconsistency of the websites, because of this, the students did not feel comfortable nor satisfied when using the website.

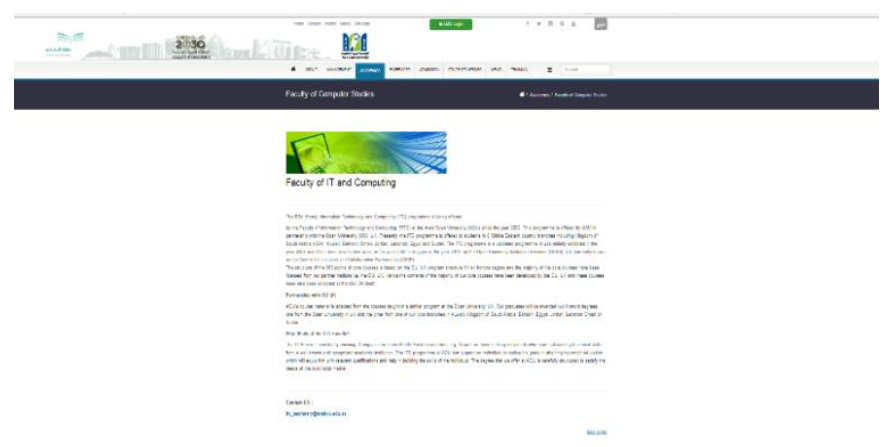

Fig. 14. Insufficient Information about the Course, Only Mentions Faculty.

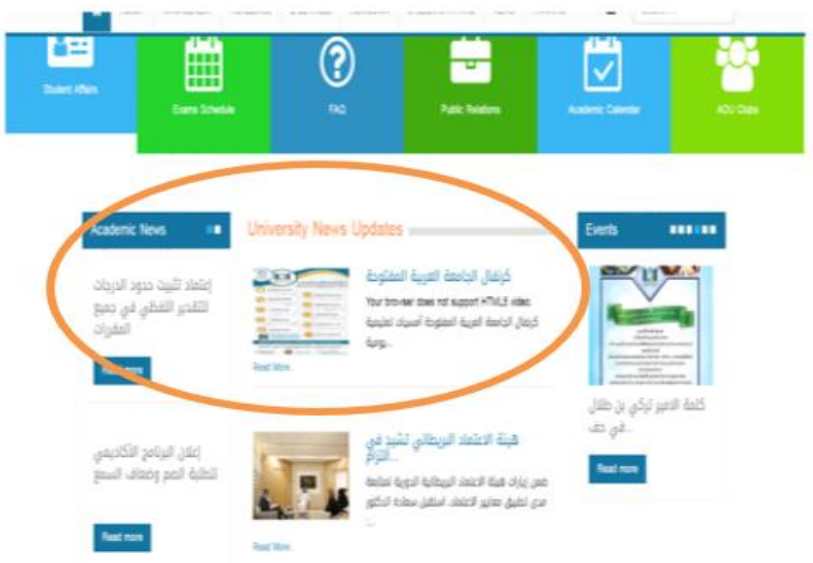

Fig. 15. Webpage Not Fully Translated.

Besides that, the translation of the content is not fully translated from Arabic to English (Fig. 15). Even the Arabic content available in certain pages are aligned in English format. Another problem which arose is the integration of the website, an example that was detected by the students was that some icons were useless as they did not direct you back to the link selected i.e. when 'academics' is selected the hyperlink does not work, likewise the home logo has no hyperlink to direct you to the home page.

\section{CONCLUSION}

The main goal of this study is to evaluate the Arabic university websites in comparison with the UK university websites. Six websites from three different university tier rankings (high, mid and low) were examined to demonstrate if there are any usability differences between the three levels. These levels were chosen to show if the different levels of university ranking influenced the usability of the website. The results showed that all Saudi university websites within the three levels (high, mid and low) shared three major problems. The problems that arose during this study were inconsistency, integration and satisfaction factors.
The results that were collated proved that the Arabic university websites faced numerous problems including satisfaction, integration, inconsistency, confidence, design concepts, ease use of websites and comfort of students. These major usability problems effect the Saudi websites directly and need to be solved urgently to attract the students and enable them to benefit from the website. Problems like mixed language, poor content, lack of information, satisfaction and icons can harm the website leading to students not interacting with the website and in the opposite way attracting content is the key feature of any effective website [33], [7], [9].

\section{LIMITATIONS OF STUDY}

Based on the number of university websites that were evaluated in this study, the quantity may limit the findings and the number of students that evaluated the websites may not be of a sufficient number to generalise the finding of this study. Besides that, the participants involved in this study were only male which may limit the results found, if male as well as females were part of the experiment it will ultimately increase the number of participants which validates the findings.

\section{FUTURE RECOMMENDATIONS}

For future research, additional usability problems within Arabic university websites should be investigated, this may include further testing of websites from different countries as well as a large number of students which includes male and females to improve the validity and the efficiency of Arabic university websites. The satisfaction of users can be reached if the designers of websites give more attention to the usability problem in order to design high quality websites.

REFERENCES

[1] C.Flavian, R. Gurrea, and C. Orús, "Web design: a key factor for the website success," Journal of Systems and Information Technology, vol. 11, no. 2, pp. 168-184, 2009.

[2] E. Liljegren, and A. L. Osvalder, "Cognitive engineering methods as usability evaluation tools for medical equipment," International Journal of Industrial Ergonomics, vol. 34, no. 1, pp. 49-62, 2004.

[3] E. Şengel, "Usability Level of a University Web Site," Procedia - Social and Behavioral Sciences, vol. 106, pp. 3246-3252, 2013.

[4] G. Shivaprasad, N. S. Reddy, U. D. Acharya, and P. K. Aithal, "NeuroFuzzy Based Hybrid Model for Web Usage Mining," Procedia Computer Science, vol. 54, pp. 327-334, 2015.

[5] ISO, "international standard organisation, ISO $9241-11-03-15$, part 11," guidance on usability 1st Edition, 1998.

[6] J. Brooke, "SUS-A quick and dirty usability scale," Usability evaluation in industry, vol. 189, no. 194, pp. 4-7, 1996.

[7] J. Hartmann, A. Sutcliffe, and A. De Angeli, "Investigating attractiveness in web user interfaces," In Proceedings of the SIGCHI conference on Human factors in computing systems, ACM, pp. 387-396, 2007.

[8] J. J. R. Lewis, and J. Sauro, "Revisiting the Factor Structure of the System Usability Scale," Journal of Usability Studies, vol. 12, no. 4, 2017.

[9] J. Melorose, R. Perroy, and S. Careas, "Usability Measurement: A Roadmap for a Consolidated Model," Statew. Agric. L. Use Baseline, vol. 1, 2015.

[10] J. Nielsen, and H. Loranger, "Prioritizing web usability," Pearson Education.,2006

[11] J. R. Lewis, and J. Sauro, "Item Benchmarks for the System Usability Scale," Journal of Usability Studies, vol. 13, no. 3, 2018. 
[12] J. R. Lewis, and J. Sauro, "The factor structure of the System Usability Scale," In Kurosu, M. (Ed.), Human Centered Design, HCII, Heidelberg, Germany: Springer-Verlag, pp. 94-103, 2009.

[13] J. R. Lewis, B. S. Utesch, and D. E. Maher, "Measuring perceived usability: The SUS, UMUX-LITE, and AltUsability," International Journal of Human-Computer Interaction, vol. 31, pp. 496-505, 2015.

[14] J. R. Lewis, B. S. Utesch, and D. E. Maher, "UMUX-LITE - When there's no time for the SUS, "In Proceedings of CHI, Paris, France: ACM, pp. 2099-2102, 2013.

[15] J. R. Lewis, J. Brown, and D. K. Mayes, "Psychometric evaluation of the EMO and the SUS in the context of a large-sample unmoderated usability study," International Journal of Human-Computer Interaction, vol. 31, no. 8, pp. 545-553, 2015.

[16] J. Sauro, "A practical guide to the system usability scale: Background, benchmarks, \& best practices," Denver, CO: Measuring Usability LLC, 2011

[17] K. Finstad, "The system usability scale and non-native English speakers," Journal of Usability Studies, vol. 1, no. 4, pp. 185-188, 2006.

[18] L. Hasan, "Can Students Complete Typical Tasks on University Websites Successfully?" In 5th International Conference on Education and Educational Technologies, pp. 141-147, 2014.

[19] L. Hasan, "Evaluating the usability of nine Jordanian university websites," In Communications and Information Technology (ICCIT), International Conference on IEEE, pp. 91-96, 2012.

[20] L. Hasan, "The Website of the University of Jordan: Usability Evaluation," Int. Arab J. e-Technology, vol. 3, no. 4, pp. 258-269, 2014.

[21] L. V. Casaló, C. Flavián, and M. Guinalíu, "The role of satisfaction and website usability in developing customer loyalty and positive word-ofmouth in the e-banking services," International Journal of Bank Marketing, vol. 26, no. 6, pp. 399-417, 2008.

[22] M. A. Ababtain and A. R. Khan, "Towards a Framework for Usability of Arabic-English Websites," Procedia Computer Science, vol. 109, pp. 1010-1015, 2017.

[23] M. Aliyu, M. Mahmud, and A. O. M. Tap, "Exploring Islamic website features that influence user satisfaction: A conceptual model," ProcediaSocial and Behavioral Sciences, vol. 65, pp. 656-661, 2012.

[24] M. Benaida, and A. Namoun, "Technical and Perceived Usability Issues in Arabic Educational Websites," International Journal of Advanced Computer Science and Applications(IJACSA), Vol. 9 no. 5, 2018.

[25] M. H. Thowfeek and M. N. Abdul Salam, "Students' Assessment on the Usability of E-learning Websites," Procedia - Social and Behavioral Sciences, vol. 141, pp. 916-922, 2014.

[26] M. Hamiti, B. Reka, and F. Imeri, "The Impact of Computer Components in Enhancing the Quality of Teaching and Learning Process in Universities," Procedia - Social and Behavioral Sciences, vol. 191, pp. 2422-2426, 2015, 2015.

[27] M. Koro-Ljungberg, E. P. Douglas, D. Therriault, Z. Malcolm, and N. McNeill, "Reconceptualizing and decentering think-aloud methodology in qualitative research," Qualitative Research, vol. 13, no. 6, pp. 735753, 2013.

[28] M. L. Frigotto, "Effectuation and the Think-Aloud Method for Investigating Entrepreneurial Decision Making," In Complexity in Entrepreneurship, Innovation and Technology Research, pp. 183-197, 2016.

[29] M. M. Elobaid, A. Lodhi and A. R. Khan, "Usability Testing of Multilingual Educational Websites," Life Science Journal, vol. 10, no. 2, 2013.

[30] M. Masood and A. Musman, "The Usability and its Influence of an eLearning System on Student Participation," Procedia - Social and Behavioral Sciences, vol. 197, pp. 2325 2330, 2015.

[31] M. T. Boren, and J. Ramey, "Thinking aloud: reconciling theory and practice," IEEE Trans. Professional Communication, vol. 43, pp. 261 $278,2000$.
[32] M. Zviran, C. Glezer, and I. Avni, "User satisfaction from commercial web sites: The effect of design and use," Information \& management, vol. 43, no. 2, pp. 157-178, 2006.

[33] P. J. Lynch, and S. Horton, "Web Style Guidelines (2nd ed.)," Yale University Press, New Haven, CT, 2001.

[34] P. Yu, and D. Zhao, "Effect of website quality factors on the success of agricultural products B2C e-commerce," International Conference on Computer and Computing Technologies in Agriculture Springer, Berlin, Heidelberg, pp. 98-113, 2013.

[35] P. Zhang, and G. von Dran, "User expectations and rankings of quality factors in different Web site domains," International Journal of Electronic Commerce, vol. 6, no. 2, pp. 9-33, 2002.

[36] Q. Whitney, "Balancing the 5Es: Usability," Cutter IT Journal, vol. 17, no. 2, 2004.

[37] R. Redekopp, and K. Kalanda, "Internet use: a study of preservice education students in Lesotho and Canada," Procedia-Social and Behavioral Sciences, vol. 182, pp. 529-534, 2015.

[38] S. B. Linek, "Order Effects in Usability Questionnaires," Journal of Usability Studies, vol. 12, no. 4, 2017.

[39] S. Borsci, S. Federici, S. Bacci, M. Gnaldi, and F. Bartolucci, "Assessing User Satisfaction in the Era of User Experience: Comparison of the SUS, UMUX, UMUX-LITE as a Function of Product Experience," International Journal of Human-Computer Interaction, Taylor \& Francis Group, LLC, vol. 31, pp. 484-495, 2015.

[40] S. Bozyigit, and E. Akkan, "Linking Universities to the Target Market via Web Sites: A Content Analysis of Turkish Private Universities' Web Sites," Procedia - Social and Behavioral Sciences, vol. 148, pp. 486-493, 2014.

[41] S. C. Peres, T. Pham, and R. Phillips, "Validation of the System Usability Scale (SUS) SUS in the Wild," In Proceedings of the Human Factors and Ergonomics Society Annual Meeting, Sage CA: Los Angeles, CA: SAGE Publications, Vol. 57, No. 1, pp. 192-196, 2013.

[42] T. K. Hoppmann, "Examining the "point of frustration"," The thinkaloud method applied to online search tasks, Quality \& Quantity, vol. 43, no. 2, pp. 211-224, 2009.

[43] T. Ramayah, N. H. Ahmad, and M. C. Lo, "The role of quality factors in intention to continue using an e-learning system in Malaysia," ProcediaSocial and Behavioral Sciences, vol. 2, no. 2, pp. 5422-5426, 2010.

[44] T. Sundeen, K. M. Vince Garland, and W. D. Wienke, "A Multi-Year Evaluation of Student Perceptions of University and Special Education Doctoral Websites," Teacher Education and Special Education: The Journal of the Teacher Education Division of the Council for Exceptional Children, vol. 39, no. 4, pp. 259-275, 2016.

[45] U. Sharkey, M. Scott, and T. Acton, "The influence of quality on ecommerce success: an empirical application of the Delone and Mclean IS success model," International Journal of E-Business Research (IJEBR), vol. 6, no. 1, pp. 68-84, 2010.

[46] W. Quesenbery, "What does usability mean: Looking beyond ease of use'," In Annual conference-society for technical communication, vol. 48, pp. 432-436, 2001.

[47] W. S. Tan, D. Liu, and R. Bishu, "Web evaluation: Heuristic evaluation vs. user testing," International Journal of Industrial Ergonomics, vol. 39, no. 4, pp. 621-627, 2009

[48] A. Agarwal and A. Hedge, "The Impact of Web Page Usability Guideline Implementation on Aesthetics and Perceptions of the ERetailer," Proceedings of the Human Factors and Ergonomics Society Annual Meeting, 2008.

[49] C.S. Ong, S.C. Chang and S.M. Lee, "Website satisfaction dimension: Factors between satisfaction and dissatisfaction," Information Development Journal, 2013.

[50] M. Mahdi and A. Maaruf, "User interface (UI) design issues for multilingual users: a case study," Universal Access in the Information Society, 2016. 